\title{
BIOLOGICALLY INFLUENCED STALAGMITES IN NIAH AND MULU CAVES (SARAWAK, MALAYSIA)
}

\author{
STALAGMITI, POGOJENI Z BIOLOŠKO AKTIVNOSTJO V JAMAH \\ NIAH IN MULU (SERAWAK, MALAZIJA)
}

\author{
Dominique DODGE-WAN ${ }^{1}$ \& Angela DENG HUI MIN ${ }^{2}$
}

\begin{abstract}
UDC 551.435.843(595)

Dominique Dodge-Wan \& Angela Deng Hui Min: Biologically influenced stalagmites in Niah and Mulu caves (Sarawak, Malaysia)

There are two significant karst regions in northern Sarawak (Malaysia): Niah and Mulu. Both are famous worldwide for their well developed caves. Here we document the presence of over twenty unusual stalagmites in six cave entrances in these two regions. One of the stalagmites has been previously described as a crayback stalagmite (Lundberg and McFarlane 2011) and they all show indications of biological influence. Our study aimed to establish the locations within the cave entrances where these stalagmites are present and to provide a preliminary overview of the stalagmite forms. The environment, and especially availability and direction of light, was also studied at several sites. Surface scrapings were examined for the presence of cyanobacteria. The morphology of the unusual stalagmites is variable and includes forms that are elongated and craybacklike and others that show features not previously described in craybacks: flat tops, bulbous protuberances, phototropic rims, irregular grooves and ridges and oriented coralloid growth. Several of these features are not found in abiotic stalagmites and suggest biological control. The findings of light surveys confirm that certain features of the stalagmites are phototropically controlled. Filamentous cyanobacteria with calcified sheaths and coccoid cyanobacteria are present. We propose that this diverse group of stalagmite be named "tufaceous stalagmite" of which craybacks are thought to be a sub-group.

Keywords: Niah, Mulu, Sarawak, stalagmite, crayback, biospeleology.
\end{abstract}

\author{
Izvleček \\ UDK 551.435.843(595) \\ Dominique Dodge-Wan \& Angela Deng Hui Min: Stalagmiti, \\ pogojeni z biološko aktivnostjo $v$ jamah Niah in Mulu (Sera- \\ wak, Malazija)
}

Na severu regije Sarawak (Malezija) sta dve pomembni kraški področji, Niah in Mulu. Obe sta svetovno znani po dobro razvitih jamah. $V$ teh dveh regijah smo $v$ šestih jamskih vhodih zabeležili več kot dvajset nenavadnih stalagmitov. Eden od stalagmitov je bil predhodno že opisan kot stalagmit »rakov hrbet« (ang. crayback, Lundberg in McFarlane 2011), in vsi nakazujejo biološki vpliv. Namen naše raziskave je bil ugotoviti posamezne lokacije $\mathrm{v}$ vhodih jam, kjer so ti stalagmiti in pripraviti pregled oblik le-teh. Okolje, še zlasti razpoložljivost in smer vpadne svetlobe, smo proučevali na več mestih. Površinski ostružki so bili pregledani na prisotnost cianobakterij. Morfologija teh nenavadnih stalagmitov je spremenljiva in vključuje podolgovate oblike, podobne stalagmitu tipa rakov hrbet ter druge, ki ne kažejo značilnosti prej opisanih - z ravnimi vrhovi, čebulasto izbočeni, robovi s fototrofnimi organizmi, nepravilne žlebove in slemena ter usmerjeno koraloidno rast. Precej teh oblik ni povezanih $\mathrm{z}$ značilnimi oblikami abiotskih stalagmitov in zato nakazujejo biološki vpliv. Pregled vpada svetlobe je potrdil, da so nekatere oblike stalagmitov pod kontrolo fototrofnih organizmov. V vzorcih so bile prisotne filamentozne cianobakterije s kalcificiranimi tulci ter kokoidne cianobakterije. Predlagamo, da se ta raznolika skupina stalagmitov imenuje "lehnjakasti stalagmit" in stalagmiti tipa rakov hrbet postanejo njihova podskupina.

Ključne besede: Niah, Mulu, Sarawak, stalagmit, stalagmit rakov hrbet, speleobiologija.

${ }^{1}$ D. Dodge-Wan, Department of Applied Geology, Curtin University, CDT 250, 98009 Miri, Sarawak, Malaysia, Tel: + 6085 443824, Fax: + 6085 443837, Email: dominique@curtin.edu.my (Corresponding author)

2 A. Deng Hui Min, Sarawak Shell Berhad, Locked Bag No.1, Lutong, Sarawak, Malaysia, Tel: + 6085 454545,

Fax: + 6085 452030, Email: Angela.Deng@shell.com

Received/Prejeto: 3.8.2012 


\section{INTRODUCTION}

There has been growing interest in the past few decades in biologically influenced cave forms, both erosional forms (such as photokarst) and depositional forms, including tufaceous stalactites and crayback stalagmites (Bull \& Laverty 1982; Cox 1984; Cox et al. 1989a; Cox et al. 1989b; Northup \& Lavoie 2001; Taboroši et al. 2005; Taboroši 2006; Mulec et al. 2007; Lundberg \& McFarlane 2011). Crayback stalagmites are elongated with hump-backed body and a segmented aspect due to transverse crenulations across their long axis. They were first described by Cox (1984) at Nettle Cave, Jenolan in NSW Australia, which is a large natural tunnel cave that receives light from several openings. The formation of crayback stalagmites involves wind deflection of ceiling drips, light triggering colonization and photosynthetic activity by cyanobacteria and accretion of aeolian material on the bacterial mucilage (Lundberg \& McFarlane 2011). Tufaceous stalactites, or calcareous tufa stalactites, are common in tropical cave entrances and on cliff faces. They are soft, fragile and often porous. They display diverse morphologies and varied petrological facies, some of which are typical of biomediated aquatic tufas (Taboroši et al.
2005). In Sarawak, tufaceous stalactites are common, photokarst has been found in the entrance of Clearwater Cave in Mulu (Bull \& Laverty 1982), a crayback stalagmite and several clusters of crayback-like stalagmites have been reported in the entrance of the Painted Cave in Niah (Lundberg \& McFarlane 2011; Dodge-Wan et al. 2012).

Crayback stalagmites have been reported in only a few localities worldwide, several of these are in Australia with others in New Zealand, USA, Thailand and Slovenia (Cox et al. 1989a; Cox et al. 1989b; Taboroši 2006; Mulec et al. 2007). The crayback at the Painted Cave was the first to be reported in Malaysia and one of very few yet discovered in Asia (Lundberg \& McFarlane 2011). Here we report on a number of biologically influenced stalagmites in two separate karst regions of Sarawak - a finding which suggests that these depositional forms may in fact be more common than previously thought. Greater awareness of their existence and morphology among the speleological community may lead to further discoveries elsewhere and a better understanding of their distribution worldwide.

\section{STUDY AREA}

There are two significant karst areas in northern Sarawak: Niah National Park and Gunung Mulu National Park (Fig. 1A). Niah is in the low-lying coastal region between Miri and Bintulu. Gunung Mulu is located further inland, over a hundred kilometres from Niah, in the Tutoh river catchment not far from the Brunei border.

The caves of Niah National Park are developed in the Subis Limestone Member of the Tangap Formation, an essentially horizontally bedded algal reef limestone of early Miocene age (Hutchison 2005). Niah Great Cave, or Gua Niah, is well known for the long-established tradition of harvesting the edible nest of swiftlets found on the cave ceilings. It is also known for several important archaeological finds in the cave sediment floor. It is a large complex cave with several spacious entrances opening in different sides of the limestone hill (Fig. 1B). The Painted Cave, or Kain Hitam, consists of an upper and lower passage, and is located in a small karst tower to the southeast of the Great Cave hill (Fig. 2 and Fig. 3).

The caves of Gunung Mulu National Park are developed in the Melinau Limestone Formation, a carbonate platform deposit of Mid-Eocene to Early Miocene age (Wannier 2009). The limestones form a series of hills aligned along the NNE-SSW strike and dipping NW at $20^{\circ}$ to $50^{\circ}$. The area of interest of this study is close to the southernmost tip of Gunung Api limestone outcrop (Fig. 1C). The formation is extraordinarily thick and one of the largest recorded carbonate units in southeast Asia (Wannier 2009). Mulu is world famous for the length and size of its caves and its spectacular karst morphology (Clark 2011).

In both of these karst areas, we have observed a number of unusual stalagmites with evidence of biological influence. They are found in the following cave entrances and are located within one to $60 \mathrm{~m}$ in from the cliff driplines:

Niah - Painted Cave (north entrance): at least 12 specimens in north facing entrance

Niah - Painted Cave (lower entrance): 1 specimen in northwest facing entrance

Niah - Great Cave (Gan Kira entrance) : 2 specimens in southeast facing entrance

Niah - Great Cave (West Mouth): 1 specimen (incomplete survey) in west facing entrance

Niah - Traders Cave: 7 specimens (incomplete survey) in west facing entrance 


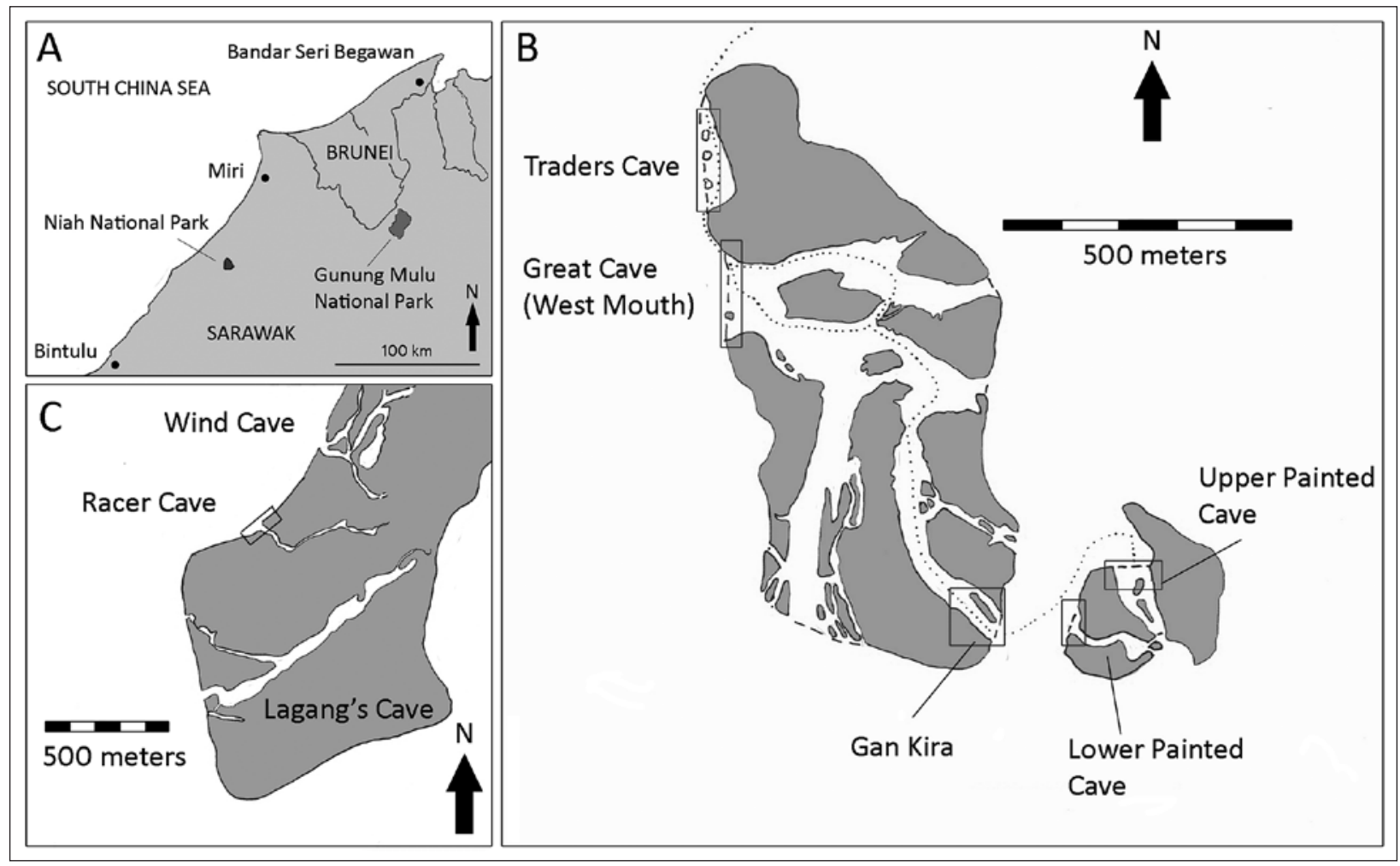

Fig. 1: A) Location map of Niah and Mulu karst regions in northern Sarawak. B) Area of interest in Niah National Park showing Traders Cave, Niah Great Cave and Painted Cave (Kain Hitam). The boxed areas are locations of biologically influenced stalagmites, but not all entrances have been surveyed. Dashed line is cliff dripline; dotted line is timber walkway and footpath. C) Area of interest in Gunung Mulu National Park showing the entrance of Racer Cave (boxed area) near southern tip of Gunung Api limestone outcrop (modified from map shown in Clark (2011) with cave passages simplified for clarity).

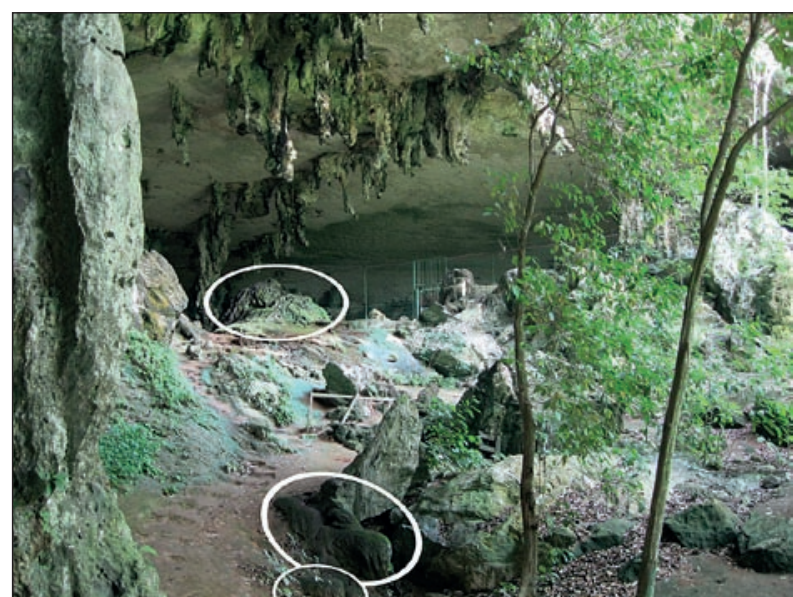

Fig. 2: North entrance of Painted Cave in Niah (upper passage) showing location of biologically influenced stalagmites (some indicated with circles). Fenced area in background is zone with cave wall paintings.

Mulu - Racer Cave : 2 specimens (incomplete survey) in northwest facing entrance

The number of stalagmites listed above may be affected by sampling bias as more field time has been devoted to the more readily accessible entrances of select-

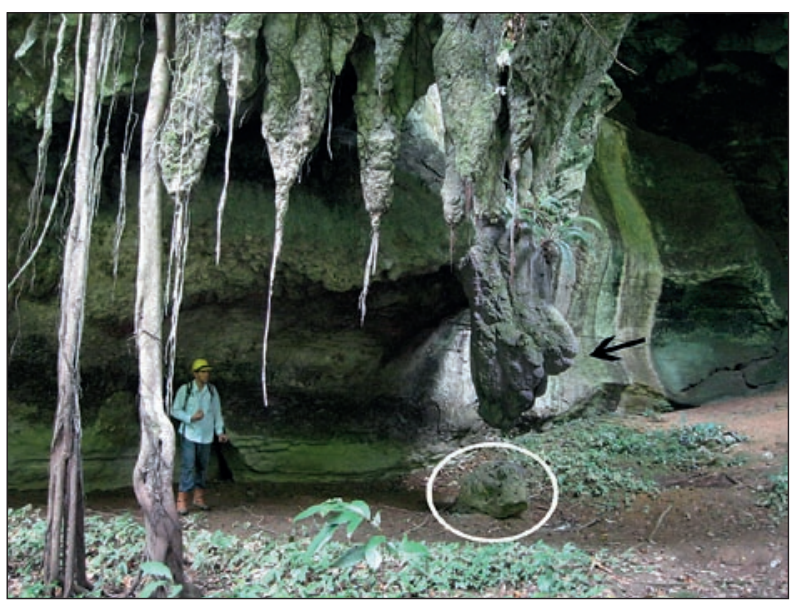

Fig. 3: Entrance to Painted Cave in Niah (lower passage). Note large bulbous tufaceous stalactites (arrow) and biologically influenced stalagmite (circled) on muddy sediment floor.

ed caves in Niah such as the Painted Cave (Fig. 2 and Fig. 3). It is probable that more biologically influenced stalagmites will be found during further surveys, both in the listed caves and other caves in Sarawak and perhaps also elsewhere in southeast Asia. 


\section{STALAGMITE MORPHOLOGY}

\section{OVERALL SHAPE}

The stalagmites listed above range in size from small forms less than $1 \mathrm{~m}$ diameter, to massive forms over $3 \mathrm{~m}$ diameter. Their height ranges from decimetres to several meters.

Some of the stalagmites are clearly elongated and have a hump-backed shape, with taller head and gently sloping tail which is consistent with the morphology of previously described craybacks (Cox 1984; Cox et al. 1989a, b; Lundberg \& McFarlane 2011; Dodge-Wan et al. 2012). The stalagmite described by Lundberg and McFarlane (2011) is of this sort. The axis of elongation of these crayback-like stalagmites points towards the cave entrance, not obliquely.

However, many of the stalagmites differ, slightly or considerably, from the typical elongated and humpbacked crayback morphology. Some are not elongated but irregularly massive (Fig. 4, Fig. 5 and Fig. 6) others are bulbous (Fig. 7) or have bulbous protuberances, whereas others are flat topped. In fact their morphology is best described as "variable". The bulbous protuberances, where present, resemble the common bulbous features of tufaceous stalactites (Fig. 3). The bulbous aspect of the stalagmites is not unlike that seen in parts of some tufa waterfalls elsewhere in the world.

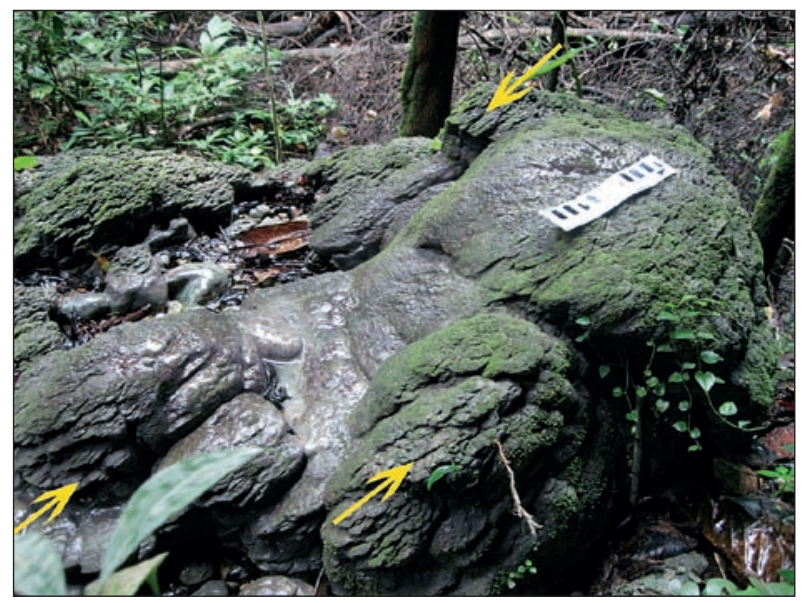

Fig. 4: Detail of stalagmite at the entrance of Racer Cave in Mulu. Note smooth wet zone, slightly recessed (near scale bar), small pool to left of centre and crenulations oriented towards the light (arrows). Scale bar is in $\mathrm{cm}$.

\section{SURFACE FEATURES}

In some stalagmites, the dampest zone at the top is recessed, either in the form of an elongated roughly linear summit groove or on the contrary an irregular shaped summit depression. In some there is ponding water. These recessed zones may be wetter and smoother than the rest of the surface and it is thought that, in that case, they are the site of maximum abiotic calcite deposition and minimal biological influence (Fig. 4). In other stalagmites the summit is not recessed. It may be flat and patterned with micro-rims (forming tiny gours) similar to those observed on abiotic speleothems and flowstones, or relatively smooth.

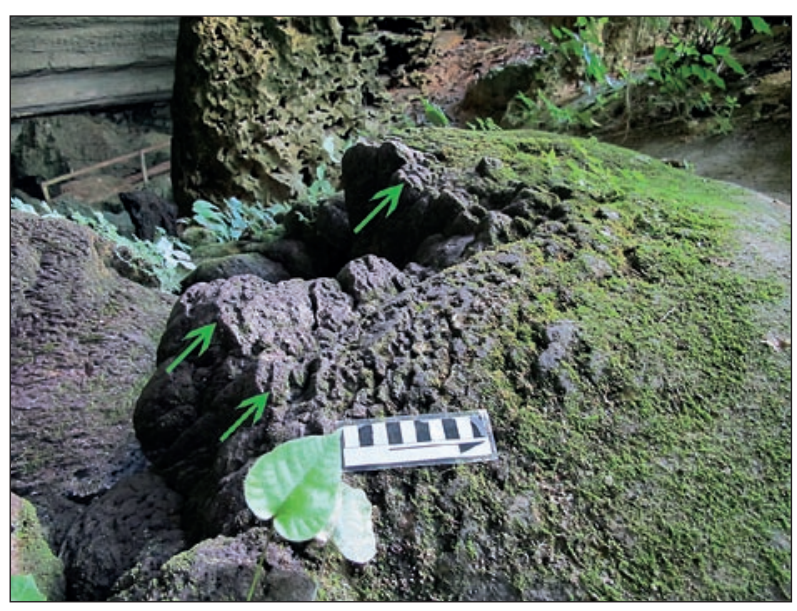

Fig. 5: Curved inclined rims running across stalagmite in Traders Cave in Niah (shown by arrows) and smaller irregular rims near scale bar (in $\mathrm{cm}$ ). Camera is approximately horizontal. Light measurement station TCS2A is at first arrow from the left and station TCS2B is at third arrow from the left.

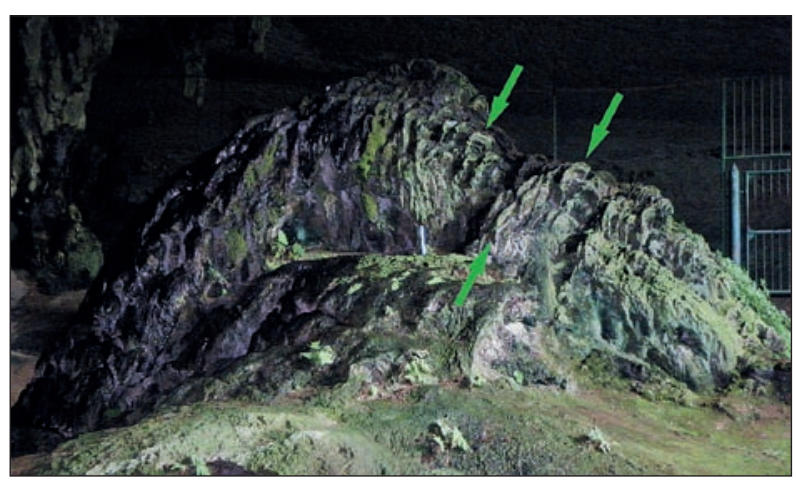

Fig. 6: Large stalagmite in Painted Cave in Niah (north entrance, upper passage) showing well developed large inclined phototropic rims (arrows). Rim concavity faces the source of natural light (entrance to the right side of photo, below the stalagmite). Ruler in centre of photo is $15 \mathrm{~cm}$ long. Natural light.

The most characteristic features of crayback stalagmites are the crenulations which give them a stepped profile. The crenulations are due to scale-like features oriented towards the light. Some, but not all, of the stalagmites described here have this type of crenulations on their upper surface (including the crayback described by 
Lundberg and Mc Farlane). Most frequently the crenulations are on the sides and they are commonly covered in moss and occasionally higher plants (Figs. 4, 6 and 7).

In places the surfaces of some of the stalagmites have a crinkled convoluted aspect (Fig. 7). The surfaces are marked by short irregular curved grooves and rounded ridges similar to the surface of the brain or brain corals. The convolutions, grooves and ridges do not show preferential orientation relative to light.

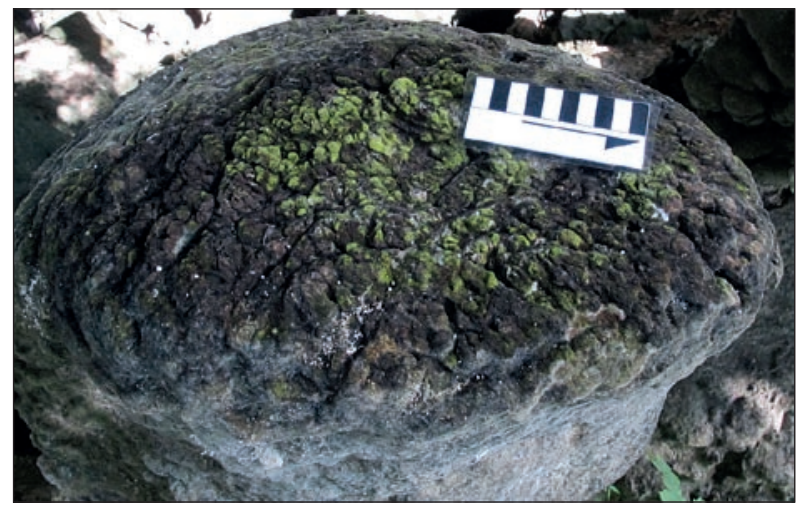

Fig. 7: Convoluted surface of stalagmite in Traders Cave in Niah. The stalagmite is slightly elongated (parallel to photograph) and parts of the top are currently colonized by mosses. Scale bar is in $\mathrm{cm}$ with arrow pointing to cave exterior.

In other places, the ridges are more continuous forming slightly undulating crests. These may extend several decimetres transversally across the stalagmites in a manner that resembles tilted wavy rimstone dams (Fig. 5 and Fig. 6). The spacing between the rims may be as little as $1 \mathrm{~cm}$ to over $10 \mathrm{~cm}$. In transverse profile they are asymmetrical and their positioning reflects the direction of dominant light, as described below. They are only found on the light-facing side of the stalagmites and their orientation shows evidence of being controlled by light, similarly to crenulations. Each rim crest appears to be located in the zone of dominant light relative to the rim "pocket" which is in the shadow cast by the rim located in front of it. The whole structure resembles a series of tilted rim pools, although the mode of formation is not possibly related to ponding water in any way. They give the stalagmite an asymmetrical stepped profile. On one unique large stalagmite in the Painted Cave (Fig. 6), the inclination of the rims is almost vertical and they form distinctive fan shaped highly asymmetrical concavo-convex pockets. The concave side of the pockets faces the entrance and the convex side faces away from the entrance. This particular stalagmite is located on high ground within the entrance zone and the brightest part of the entrance is below the stalagmite (not above) which may explain the almost vertical aspect of the rims.
In all the other cases, the brightest part of the entrance is above the stalagmites. To the authors' knowledge this type of feature has not previously been described in any speleothem although the previously reported crenulations are probably related. It is possible that lateral crenulations are the lateral expression of inclined rims. We suggest that the tilted rims be named "phototropic rims". Their orientation relative to light is described below.

Two of the stalagmites have an additional feature of interest - oriented coralloid growths pointing to the entrance on their entrance-facing sides and front. These two stalagmites are both located in the Gan Kira passage of Niah Great Cave approximately $60 \mathrm{~m}$ in from the entrance dripline (Fig. 1B). This location is the darkest of the observed stalagmite locations. It is also a location with noticeable cave wind.

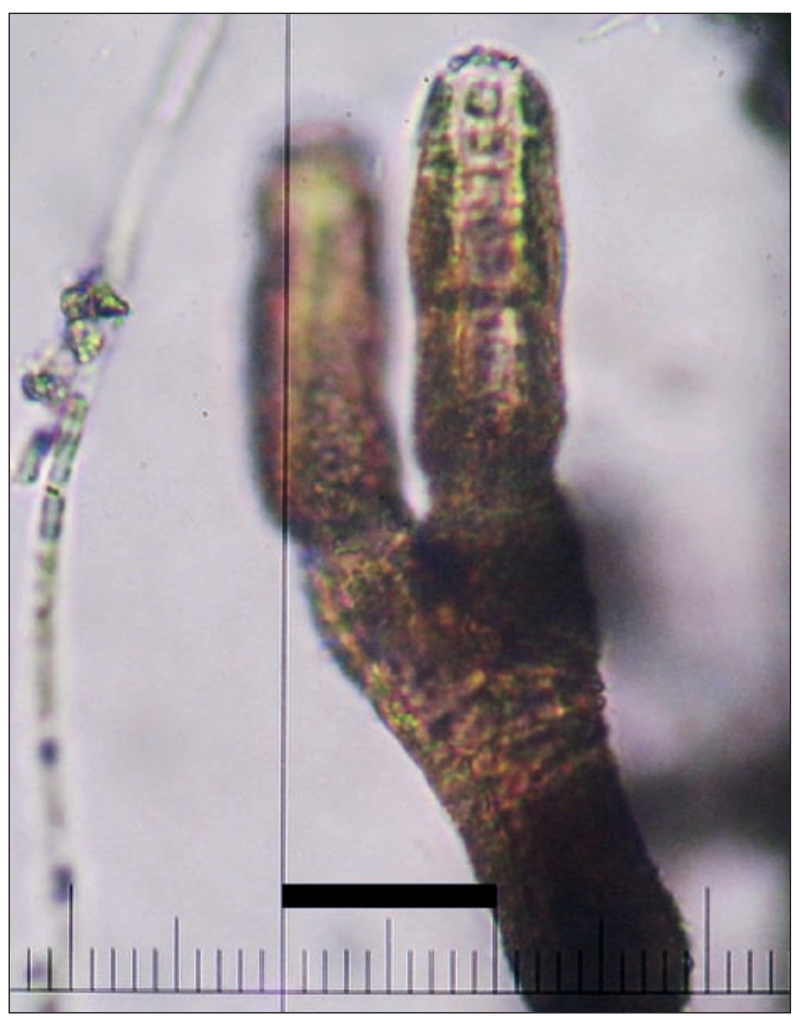

Fig. 8: Calcified filamentous cyanobacteria from the stalagmite circled in Fig. 3 (Painted Cave in Niah, lower entrance). The dichotomously branching calcified cyanobacteria are possibly Geitleria calcarea. Thick black scale bar is 25 microns long.

\section{COLOUR}

When wet, the stalagmites are dark, with generally purple to dark brown colours being the most common, particularly in their summit areas. The purple coloration is the millimetre thick outermost layer of mineralized material and biofilm. Below this layer (as observed in scrapings and where surface is damaged) the colour is lighter, typi- 
cally a buff earthy hue. The purple colouration is most characteristic of the currently active areas of these stalagmites. It is similar to the colour observed in the wetter lower parts of tufaceous stalactites (some are shown in Fig. 3). It corresponds to 10R 4/1 soil colour (Munsell Color 1975), or similar ("dark reddish grey") depending on degree of wetness. It passes in places to a light purple grey (similar to 10R 6/1).The sides of the stalagmites, away from the most active areas, may be colonized by vegetation, such as mosses and ferns or coated with soft green biofilm (as on stalagmites shown in Figs. 4 and 5 for example). Inactive stalagmites may also be colonized (Fig. 7). The blue colours reported in Australian craybacks (Cox et al. 1989a, b) have not been seen in any of the Sarawak specimens.

\section{MICROCLIMATIC CONDITIONS: LIGHT}

Light is a key limiting factor to growth of photosynthetic organisms in caves. The stalagmites described here are found in large cave entrances but partially protected from direct sun by rainforest vegetation outside the cave and, in some places, by adjacent large speleothem columns, which also partially block incoming light. None of the stalagmites are exposed to full sunlight. Even those that are closest to the cave entrances are shaded by vegetation which provides mottled shadows. The stalagmites are located at distances from cliff driplines that range from a few meters to over $60 \mathrm{~m}$. The majority are within $20 \mathrm{~m}$ of the dripline. They are growing either on sediment floor, on fallen limestone blocks or on other stalagmites. Their supporting surfaces may be horizontal or inclined, and inclined in any direction. So the supporting surface may be angled towards the light or away from the light.

Light levels have not been measured in a systematic way at all sites, but several sites have been surveyed in an attempt to quantify the maximum light intensity in the vicinity of the stalagmites at mid-day on a bright sunny day. The measurements were made using a Model 1300 Clas Ohlsen 32-7361 photometric light meter which provides readings in lux. Conversion into photon flux density unit $\left(\mu \mathrm{mol} . \mathrm{m}^{-2} . \mathrm{s}^{-1}\right)$ which is the unit more commonly used in microbiological research, has been carried out using the conversion factor of $54 \mathrm{lux}=1 \mu \mathrm{mol} . \mathrm{m}^{-2} \cdot \mathrm{s}^{-1}$ for sunlight (400-700 $\mathrm{nm}$ wavelength) as proposed by Thimijan and Heins (1983).

The results indicate maximum intensities that range from a low of 19lux $\left(0.35 \mu \mathrm{mol} . \mathrm{m}^{-2} . \mathrm{s}^{-1}\right)$ which is the brightest light falling on darkest of the surveyed stalagmites to a high of around $2200 \operatorname{lux}\left(40.7 \mu \mathrm{mol} . \mathrm{m}^{-2} \cdot \mathrm{s}^{-1}\right)$ which is the brightest light on the brightest of the surveyed stalagmites. The darkest stalagmites observed in this study are two specimens located $60 \mathrm{~m}$ in from the Gan Kira entrance of the Great Cave of Niah where oriented coralloid growth is present (Fig. 1B). Between the brightest and darkest extremes, most of the stalagmites are situated in zones where the brightest light is between 20 and 300 lux (between 0.37 and $5.6 \mu \mathrm{mol} . \mathrm{m}^{-2} . \mathrm{s}^{-1}$ ). Light

Tab. 1: Light intensity recorded at eight different compass bearings around stalagmites in Traders Cave (Niah, Sarawak) around midday on 2 July 2012 and strike of stalagmite rims for comparison.

\begin{tabular}{|c|c|c|c|c|c|}
\hline \multicolumn{2}{|c|}{ Stalagmite measurement location } & TCS1 & TCS2A & TCS2B & TCS3 \\
\hline \multicolumn{2}{|c|}{ Strike of stalagmite rims } & $025^{\circ}$ & $160^{\circ}$ & $168^{\circ}$ & $140^{\circ}$ \\
\hline \multicolumn{2}{|c|}{ Compass bearing of lightmeter } & \multicolumn{4}{|c|}{ Light intensity (lux) } \\
\hline $270^{\circ}$ & W ( $1^{\text {st }}$ reading) & 47 & 258 & 230 & 109 \\
\hline $315^{\circ}$ & $\mathrm{N}-\mathrm{W}$ & 103 & 117 & 83 & 23 \\
\hline $000^{\circ}$ & $\mathrm{N}$ & 86 & 21 & 34.3 & 9.8 \\
\hline $045^{\circ}$ & N-E & 41 & 15.3 & 18.3 & 9.8 \\
\hline $090^{\circ}$ & $\mathrm{E}$ & 7.6 & 16 & 16.6 & 9.8 \\
\hline $135^{\circ}$ & S-E & 5.5 & 51.3 & 20 & 14.4 \\
\hline $180^{\circ}$ & $\mathrm{S}$ & 5.5 & 171 & 184 & 59 \\
\hline $225^{\circ}$ & S-W & 7 & 295 & 258 & 103 \\
\hline $270^{\circ}$ & $W\left(2^{\text {nd }}\right.$ reading $)$ & 39 & 276 & 209 & 83 \\
\hline
\end{tabular}


levels today can be expected to be higher than in the past due to gradual cliff line retreat.

A more detailed survey of light orientation in the vicinity of three stalagmites with tilted rims was conducted to compare the orientation of the rims (i.e. strike) and the orientation of light entering the cave at these locations. The stalagmites (TCS1, TCS2 and TCS3) are located respectively $3 \mathrm{~m}, 6.6 \mathrm{~m}$ and $16.2 \mathrm{~m}$ in from the N-S oriented cliff dripline at Traders Cave, Niah. At TCS2 measurements were taken at two positions (TCS2A and TCS2B). Although the three stalagmites are in the same cave entrance, they are not illuminated in the same way due to adjacent speleothem columns and other localised obstructions casting shadows. The strikes of the stalagmite rims are $025^{\circ}, 160^{\circ}, 168^{\circ}$ and $140^{\circ}$ respectively. Field observations suggest that this variability is due to local variations in the orientation of dominant light due to shadowing by obstructions. To test this hypothesis and to quantify the difference in light orientation around the three stalagmites, a survey was conducted on 2 July 2012 between $12 \mathrm{am}$ and $2 \mathrm{pm}$. At each of the four loca- tions light intensity measurements were taken at 8 different compass bearings in a horizontal plane. The results are presented in Tab. 1.

The results show that the light is very directional and that the brightest and darkest directions are not identical in all locations. The brightest side of the stalagmites was found to be an order of magnitude brighter than the darkest side. During this survey, the brightest mid-day light intensity ranged from approximately 100 to $300 \operatorname{lux}\left(1.9\right.$ to $\left.5.6 \mu \mathrm{mol} . \mathrm{m}^{-2} \cdot \mathrm{s}^{-1}\right)$ and the darkest ranged from approximately 5 to 20 lux ( 0.1 to $\left.0.4 \mu \mathrm{mol} \cdot \mathrm{m}^{-2} \cdot \mathrm{s}^{-1}\right)$. In each of the four cases, the strike of the stalagmite rims is close to the bisector between the brightest and darkest quadrants. In other words, the strike of the rims is close to perpendicular to the brightest and the darkest directions. This supports the hypothesis that the rim orientations are controlled by light. The survey also showed that not much light is reflected off the ceiling or off other closer features such as blocks or the distant east cave wall.

\section{MICROCLIMATIC CONDITIONS: HYDROLOGY}

The stalagmites are most commonly located below stalactites that are clearly tufaceous, some of which are deflected towards the light and others that are not deflected. There is considerable variability in the morphology of the stalactites above. Some are single relatively slender deflected tufaceous stalactites (Fig. 2). Others are clustered groups of vertical hanging massive bulbous tufa- ceous forms (Fig. 3). The stalagmites currently appear to either be dry (inactive) or infrequently dripped on, with considerable daily and seasonal variation in drip flow depending on rainfall. Drip fall heights (from tip of stalactite above to top of stalagmite below) range from $12 \mathrm{~m}$ to less than $1 \mathrm{~m}$.

\section{MICROCLIMATIC CONDITIONS: WIND}

Some locations have noticeable cave wind. This may have several consequences: displacement of falling drip water off its vertical trajectory, leading to growth of an elongated stalagmite, deflection of tip of stalactite due to wind (or phototropic growth, with the same result) and variable evaporation rates in different zones around the stalagmite. Fig. 2 shows deflected stalactites growing from the ceiling of the Painted Cave.

Some of the locations are not windy, in particular the Lower Painted Cave entrance and the Racer Cave en- trance. These are both in a relatively sheltered position at valley level with adjacent forest (Figs. 3 and 4). Furthermore, in these two locations the stalagmites are not situated in line with the path of expected circulating cave wind in or out of the cave. It therefore seems that wind is not a requirement for the genesis of these stalagmites although it does appear to influence their morphology, leading to elongated forms. Some elongated craybacklike stalagmites are probably abiotic (Dodge-Wan et al. 2012). 


\section{CYANOBACTERIA}

A limited amount of surface scraping sampling has been carried out on the stalagmites in Niah (under permit) and samples examined with transmitted light microscope. Filamentous and coccoid cyanobacteria are common and diverse. The filamentous cyanobacteria form mats and calcified cyanobacterial sheaths have been found in the purple to grey zones of the stalagmites (Fig. 8). The calcified filaments are approximately 18 to 20 microns diameter and show irregular constrictions on their cal- cified outer surface. The trichomes are visible in places where the calcified sheaths are broken and sometimes visible through the calcified sheaths. Trichome diameter is approximately 8 microns. The calcified filaments are dichotomously branching and are tentatively identified as Geitleria calcarea Friedmann, a species found in other cave entrances in a number of localities around the world (Friedmann 1979; Couté 1982). In some of the Niah samples diatoms are also present but rare.

\section{DISCUSSION}

Twenty unusual stalagmites have been examined in this study and a number of features suggest that they are biologically influenced. They are:

Their outer surfaces are purple, dark brown, grey and other dark colours which are not typical of abiotic stalagmites.

Below the millimetre thick biotic outer layer the colour is lighter, typically a buff earthy hue.

The stalagmites are located exclusively in cave entrances, in locations where maximum light intensity ranges from below 20lux to around 2200lux (approximately 0.4 to $5.5 \mu \mathrm{mol} \cdot \mathrm{m}^{-2} \cdot \mathrm{s}^{-1}$ ). None were observed in totally dark zones.

They are located in vicinity of tufaceous stalactites.

Their overall morphology differs from that of abiotic stalagmites forming under the variable influences of gravity, degassing and/or evaporation and wind.

They have crenulations oriented towards the light (most noticeable on their sides).

Some have phototropic rims - these are oriented perpendicular to incoming light and only found on their light-facing sides.
Some have bulbous features resembling those observed in non-subterranean tufa waterfalls (cascades).

Some have irregular surfaces with grooves and ridges (resembling the surface of brains) that are not found in abiotic stalagmites.

The lighting levels are comparable to those observed in the vicinity of craybacks at Nettle Cave, NSW Australia, where Cox et al. (1989a) report 11 to 700lux (approximately 0.2 to $13 \mu \mathrm{mol} \cdot \mathrm{m}^{-2} \cdot \mathrm{s}^{-1}$ ). The lighting levels are similar to the range of 7.72 to $11.11 \mu \mathrm{mol} . \mathrm{m}^{-2} \cdot \mathrm{s}^{-1}$ , which is the indirect sun illumination that prevails around a cluster of 21 stromatolitic stalagmites in the Schmidlova dvorana cave entrance (Skocjanske jame, Slovenia) where cyanobacteria have been identified (Mulec et al. 2007). The results indicate that neither excessive light, nor insufficient light, is a limiting factor to cyanobacterial growth at these locations in the Niah and Mulu cave entrances and indeed there is much evidence of abundant cyanobacterial colonization in these cave entrances.

\section{CONCLUSIONS}

This research suggests that biologically influenced stalagmites, of which only a few specimens have been documented worldwide to date, may in fact be relatively common in tropical caves with large entrances where tufaceous stalactites are also common. The morphology of biologically influenced stalagmites found in these locations is highly variable and many differ from the characteristic crayback stalagmite morphology.
We propose that this type of stalagmite be simply called tufaceous stalagmite. It is suggested that craybacks are a sub-type of tufaceous stalagmite, restricted to the specific cases where cave wind and/or deflection of a stalactite above has caused the locus of drip fall point to be spread along the axial orientation of the stalagmite. The strongest arguments in favour of biological control of calcification are the phototropic features. Calcified 
filamentous cyanobacteria are present on the surfaces of these stalagmites. Further research is required to better document the stalagmite morphology, microstructure, environmental conditions, cyanobacteria and plant colonization and to understand their genesis.

\section{ACKNOWLEDGEMENTS}

The authors thank the Sarawak Forest Department for permission to conduct research under permit (Permit No NCCD.907.4.4 (Jld.VI)-87 and Park permit No. 202/2012), the Sarawak Forestry Corporation for assist- ance and Curtin University (Miri) for financial support. Thanks also to Joyce Lundberg and Donald A. McFarlane for advice on cave surveying methods and valuable discussions on craybacks and photokarst.

\section{REFERENCES}

Bull, P. A., \& M. Laverty, 1982: Observations on phytokarst. - Z. Geomorphol., 26, 437-457.

Clark, B., 2011: Mulu World Heritage Area - Borsamulu Park Enterprise Sdn. Bhd., pp.104, Kuching.

Couté, A., 1982: Ultrastructure d'une cyanophycée aérienne calcifiée cavernicole: Geitleria calcarea Friedmann.- Hydrobiologia, 97, 255-274.

Cox, G., 1984: Phototropic stalagmites at Jenolan Caves N.S.W. - Helictite, v. 22, 54-56.

Cox, G., James, J.M., Armstrong, R. A. L. \& K. E. A. Legget, 1989: Stromatolitic crayfish-like stalagmites.Proceedings of the University of Bristol Spelaeological Society, 18, 339-358.

Cox, G., James, J.M., Legget, K. E. A. \& R. A. L. Osborne, 1989: Cyanobacterially deposited speleothems: subaerial stromatolites.- Geomicrobiology Journal, 7, 245-252.

Dodge-Wan, D., Deng, A.H.M. \& M.F. Abbas, 2012: Occurrence and morphology of crayback-like stalagmites in the Painted Cave of Niah (Sarawak, Malaysia).- Carbonates and Evaporites, 27 (3-4), 343-356..

Friedmann, E.I., 1979: The Genus Geitleria (Cyanophyceae or Cyanobacteria): Distribution of G. calcarea and G. floridana n. sp.- Plant Systematics and Evolution, 131, 169-178.

Howie, F. M. P. \& P. J. Ealey, 2011: Coastal tufa and speleothems of Prussia and Stackhouse Coves, SouthWest Cornwall.- Geoscience in South-West England, 12, 278-287.

Hutchison, C. S., 2005: Geology of North-West Borneo.Elsevier, pp. 421, Amsterdam.
Lundberg, J. \& D. A. Mc Farlane, 2011: A note on the occurrence of a crayback stalagmite at Niah Caves, Borneo. - International Journal of Speleology, 40, 1, 39-43.

Mulec, J., Kosi, G. \& D. Vrhovšek, 2007: Algae promote growth of stalagmites and stalactites in karst caves (Škocjanske Jame, Slovenia). - Carbonates and Evaporites, 22, 6-9.

Munsell Color, 1975: Munsell Soil Color Charts.- Munsell Color Division of Kollmorgen Corporation, pp. 19, Baltimore.

Northup, D. E. \& K.H. Lavoie, 2001: Geomicrobiology of caves - a review. - Geomicrobiology Journal, 18, 199-222.

Taboroši, D., 2006: Biologically influenced carbonate speleothems. - Geological Society of America, Special Paper 404, 307-317.

Taboroši, D., Hirakawa, K. \& T. Sawagaki, 2005: Carbonate precipitation along a microclimatic gradient in a Thailand cave - Continuum of calcareous tufa and speleothems. - Journal of Cave and Karst Studies, 67, 1, 69-87.

Thimijan, R.W. \& R.D. Heins, 1983: Photometric, radiometric, and quantum light units of measure: a review of procedures for interconversion. - Hort Science, $18(6), 818-822$.

Wannier, M., 2009: Carbonate platforms in wedge-top basins: An example from the Gunung Mulu National Park, Northern Sarawak (Malaysia). - Marine and Petroleum Geology, 26, 177-207. 